\title{
ON A FIXED POINT THEOREM IN UNIFORM SPACES AND ITS APPLICATION TO NONLINEAR VOLTERRA TYPE OPERATORS
}

\author{
VASIL ANGELOV*, HRISTO KISKINOV** , ANDREY ZAHARIEV*** \\ AND LJUBOMIR GEORGIEV* \\ *Department of Mathematics, University of Mining and Geology St. I. Rilski, \\ 1700 Sofia, Bulgaria \\ E-mail: angelov@mgu.bg lubo_62@mgu.bg \\ ** Faculty of Mathematics and Informatics, University of Plovdiv, \\ 236 Bulgaria Blvd., 4003 Plovdiv, Bulgaria \\ E-mail: kiskinov@uni-plovdiv.bg \\ *** Faculty of Mathematics and Informatics, University of Plovdiv, \\ 236 Bulgaria Blvd., 4003 Plovdiv, Bulgaria \\ E-mail: zandrey@uni-plovdiv.bg
}

\begin{abstract}
In the present work, we prove a fixed point theorem for nonlinear operators acting in Hausdorff sequentially complete uniform spaces whose uniformity is generated by a saturated family of pseudometrics. As an application we consider nonlinear abstract Volterra type integral equations of second kind in the case when the independent variable belongs to arbitrary completely regular Hausdorff space. Existence and uniqueness of the solutions of these equations in nonhomogeneous case are also proved.
\end{abstract}

Key Words and Phrases: Fixed point, Volterra type integral equations, uniform space, pseudometrics, Hausdorff space.

2010 Mathematics Subject Classification: 47H10, 47J05, 54E15, 45N05, 45D99.

Acknowledgement. This research has been partially supported by Plovdiv University NPD grant NI13 FMI-002.

\section{REFERENCES}

[1] R.P. Agarwal, M. Meehan, D. O'Regan, Fixed Point Theory and Applications, Cambridge University Press, 2004.

[2] R.P. Agarwal, D. O'Regan, P.J.Y. Wong, Constant-Sign Solutions of Systems of Integral Equations, Springer, 648 (2013).

[3] R.P. Agarwal, D. O'Regan, Infinite Interval Problems for Differential, Difference, and Integral Equations, Kluwer Academic Publishers, Dordrecht, Netherlands, 350(2001).

[4] V.G. Angelov, Fixed Points in Uniform Spaces and Applications, Cluj University Press, ClujNapoca, 229(2009).

[5] J.M. Appell, A.S. Kalitvin, P.P. Zabrejko, Partial Integral Operators and Integro-Differential Equations, Monographs and Textbooks in Pure and Applied Mathematics, Marcel Dekker, Inc., NY, 569(2000). 
[6] D.D. Bainov, S.I. Kostadinov, A.I. Zahariev, Abstract Volterra type integral equations, Bull. Instit. Math. Academia Sinica, 16(1988), 93-104.

[7] D.D. Bainov, A.D. Myshkis, A.I. Zahariev, On an abstract analog of the Bellman-Gronwall inequality, Publ. RIMS, Kyoto University, 20(1984), 903-911.

[8] V. Berinde, Iterative Approximation of Fixed Points, Springer, 2007.

[9] R.E. Edwards, Functional Analysis, Holt, Rinehart and Winston, 1965.

[10] I.E. Guryanova, A.D. Myshkis, Nonextendable solutions of abstract Volterra type integral equations, (in Russian), Diff. Equations, 22(1986), 1786-1789.

[11] E. Hille, R. Phillips, Functional Analysis and Semi-groups Amer. Math. Soc. Colloquium Providence, 1957.

[12] B.G. Pachpatte, Multidimensional Integral Equations and Inequalities, Atlantis Studies in Mathematics for Engineering and Science, Vol. 9, Atlantis Press, Amsterdam - Paris, 256(2011).

[13] I.A. Rus, Generalized Contractions and Applications, Cluj University Press, Cluj-Napoca, 2001.

[14] I.A. Rus, A. Petruşel and G. Petruşel, Fixed Point Theory 1950-2000: Romanian Contributions, House of the Book of Science, Cluj-Napoca, 2002.

[15] I.A. Rus, Fixed Point Structure Theory, Babeş-Bolyai University, Cluj University Press, ClujNapoca, 2006.

[16] J.M. Ayerbe Toledano, T. Dominguez Benavides, G. López-Acedo, Measures of Noncompactness in Metric Fixed Point Theory, Springer Basel, 1997.

[17] A. Zahariev, A. Georgieva, L. Trenkova, On Volterra type integral equations in noncompact metric space, J. Ineq. Appl., 260(2014), 1-17.

Received: June 24, 2014; Accepted: October 09, 2014. 